Article

\title{
Poverty and Environmental Degradation in Southern Burkina Faso: An Assessment Based on Participatory Methods
}

\author{
Daniel Etongo ${ }^{1, *}$, Ida Nadia S. Djenontin ${ }^{2}$ and Markku Kanninen ${ }^{1,3}$ \\ 1 Viikki Tropical Resources Institute, Department of Forest Sciences, University of Helsinki, \\ Latokartanonkaari 7, P.O. Box 27, Helsinki 00014, Finland; markku.kanninen@helsinki.fi or \\ m.kanninen@cgiar.org \\ 2 West Africa Regional Office (WARO), Center for International Forestry Research (CIFOR), 06 P.O. Box 9478, \\ Ouagadougou 06, Burkina Faso; I.Djenontin@cgiar.org \\ 3 Center for International Forestry Research (CIFOR), Bogor 16115, Indonesia \\ * Correspondence: daniel.etongobau@helsinki.fi; Tel.: +358-449-151-781; Fax: +358-919-158-100
}

Academic Editors: Claudia A. Radel and Jacqueline M. Vadjunec

Received: 31 July 2015; Accepted: 4 June 2016; Published: 24 June 2016

\begin{abstract}
The poverty and environmental degradation vicious circle hypothesis considers the poor as agents and victims of environmentally degrading activities. Despite some studies, however, there still has not been a sufficient empirical examination of the poverty-environment nexus. Based on participatory poverty assessment (PPA) methods with two hundred farm households categorized by wealth status in southern Burkina Faso, six indicators of environmental degradation and a set of land management practices were examined to answer the following questions: (i) Which households (non-poor, fairly-poor, or poorest) are responsible for environmental degradation? (ii) Does poverty constrain adoption of land management practices considered to improve the land? Results indicate deforestation is highest for non-poor farmers, and non-poor and fairly-poor farmers have higher rates of overgrazing. In addition, the entire non-poor group, mainly recent migrants to the area, occupy borrowed lands with tenure perceived as insecure, considered by farmers to be a disincentive for assisted natural regeneration of vegetation. Thus, non-poor and fairly-poor farmers participate most in activities locally identified as environmentally degrading, and the former contribute more than the latter. On the other hand, adoption of land management practices considered to improve the land is relatively low amongst the poorest farmers.
\end{abstract}

Keywords: poverty; tenure security; deforestation; land management practices; Burkina Faso

\section{Introduction}

Until the last decade, the concept of a vicious circle, fostered by the World Bank $[1,2]$ and related international agencies [3], dominated the debate on poverty-environment linkages. This concept first appeared in the Brundtland Report launched by the World Commission on Environment and Development (WCED) [4]. According to this report, "Many parts of the world are caught in a vicious downward spiral: poor people are forced to overuse environmental resources to survive on a daily basis, and their impoverishment of their environment further impoverishes them, making their survival more uncertain and difficult" ([4]; p. 27). Contrary to the assumptions of WCED, later studies [5-7] show that poverty-environment linkages do not conform to a simple downward-spiraling two-way relationship. According to these findings, existing social networks and institutions that govern access to natural resources mediate the relationships between poverty and environmental degradation and improvement. In addition, the popular portrayal of the vicious circle has treated poverty in uniform and generic ways and thereby caused the broader context behind this poverty to be 
under-represented. Given that the natural resource base constitutes an important source of income in rural developing countries, especially for the poorer groups in society, a better understanding of the poverty-environment relationship can lead to better policies that support the natural resource assets of the poor.

Poverty itself is contextualized differently across academic disciplines and regions of the world [8]. It is now generally accepted that human poverty has many dimensions, and it is not just poverty of income or not having things necessary for material well-being. Human poverty also means the deprivation that people suffer throughout their lives which differs among nations. Furthermore, differences occur within developing countries when rural areas are compared to their urban counterparts. The result has been the emergence of different ways of approaching poverty-environmental linkages. On one hand, the state of the environment is increasingly a focus of development practitioners when determining the magnitude of poverty. On the other hand, a major concern for environmentalists is the role of poverty in resource degradation [9]. While the former focuses on the poor state of the environment as a factor in pushing rural households that are dependent on natural resources into poverty, the latter concerns itself with the poor as agents of environmental degradation [10]. Can the potential reinforcing interactions between environmental degradation and poverty provide explanations as to why this relationship is far from being linear? Additional empirical research is needed to further specify the relationship.

In addition, the poverty-environment vicious circle hypothesis suggests that economic growth is needed to break the poverty-environment downward spiral. Economic growth policies are expected to reduce poverty while providing incentives for investment in the land [10]. However, a simple generalization of the relationship between poverty and environmental degradation is misleading [9]. This is because economic growth is not always inclusive of the poor and policy instruments often fail to address inequality. On the other hand, previous studies have limited environmental degradation to soil erosion and deforestation at the expense of attention being paid to other environmentally degrading activities such as overgrazing, use of pesticides, etc. [6]. Understanding the environmental entitlements or resource rights of farmers provides valuable information for understanding land-use decision making [11,12].

In Burkina Faso, approximately 70 percent of the population is rural and depends on farming and livestock for their livelihoods [13]. The rural population depends on the natural resource base and adopts different resource management strategies that can either improve or degrade the environment. The study reported here examines the role of different rural wealth groups in contributing to environmental degradation in four rural communities in southern Burkina Faso. Given that many farmers in the Sahel manage complex crop and livestock portfolios [8], expanding the focus to include other environmentally degrading activities aside from soil erosion and deforestation is invaluable for further understanding of the poverty-environment nexus in the Burkina Faso context. Previous Burkina Faso studies identify the cutting and selling of fuel wood [13,14], cotton cultivation [15], and the conversion of forests to croplands [16] as the main drivers of environmental degradation. However, studies on the relationship between individual wealth status and environmentally degrading activities are lacking.

For the purposes of this study, environmental degradation is defined as the deterioration of the environment through depletion of resources such as air, water and soil, leading to the destruction of ecosystems and the extinction of wildlife [17]. This study focuses on the depletion and degradation of land and forest resources as examples of environmental degradation. In addition to the above cited activities, overgrazing resulting from livestock stocking densities that exceed the available fodder supply is also considered to be a cause of degradation of land and forest resources [18]. Agro-pastoral systems dominate in the Sahel, and livestock numbers have increased significantly during the last 30 years in southwestern Burkina Faso [19]. Such increases inevitably lead to increases in rangeland and fodder demand that is likely to affect the management of natural resources and especially forests. Understanding the livelihood activities of farming households characterized by different 
economic means will provide insight into the natural resource management problems implicit in poverty-environment linkages. These problems are considered to be largely related to agriculture [20] and may be responsible for the depletion of both individual and common-pool resources.

Southern Burkina Faso offers greater opportunities for rain-fed agriculture, fuel wood supply, forest and tree products, fodder supply, etc., compared to the country's central and northern regions, which suffer from periodic drought. The favorable climate and soil conditions attract migrants and agribusiness investors in search of arable land. Increased demand for land has caused land scarcity [21] and resulted in higher competition among different land uses [22], which not only threatens environmental sustainability [16] but also causes deforestation [23,24]. Consequently, previous studies in Burkina Faso $[16,23,24]$ focus on population-environment rather than poverty-environment interactions. Although these studies are important for assessing land degradation, they address only some of the potential causes. This study tests the poverty-environment relationship through the following questions: (i) When households are categorized based on poverty and wealth, which groups are more responsible for environmental degradation? (ii) Does poverty constrain the adoption of land management practices that are considered to improve the land? Understanding the relationship between poverty, wealth, and natural resource management activities leading to environmental degradation is important for prescribing policy measures to mitigate these problems.

\section{Materials and Methods}

\subsection{Description of Study Area}

This paper is based on field research conducted in four adjacent community forest villages: Cassou, Vrassan, Dao, and Kou, all in the Ziro province, southern Burkina Faso (Figure 1). These villages were chosen under the framework of the Building Biocarbon and Rural Development (BIODEV) project in West Africa. This project was financed by Finland's Ministry of Foreign Affairs as an initiative to achieve developmental benefits by building biological and natural carbon resources through improved agroforestry and forest management practices. This area lies within the South-Sudanian climate zone, with annual precipitation of $800-1000 \mathrm{~mm}$. Rains consisting of short intense storms fall over a single wet season lasting for approximately four months from June to September [25]. During the hot season, the average daily temperature stands at $30^{\circ} \mathrm{C}$, with peaks of $40^{\circ} \mathrm{C}$ as a result of hot dry air that blows from the Sahara Desert. The area is characterized by low relief and homogenous soil types including silt-clay cambisols, sandy lixisols, and loamy ferric luvisols [26].

The average population density in the Ziro province was estimated at 28 persons $/ \mathrm{km}^{2}$ in 2006 [27], but this figure is increasing due to rural-rural in-migration [16]. The population consists of three main ethnic groups: Gourounsi (indigenous), Mossi (originating from the central plateau) and Fulani (originating from the north of Burkina Faso).

The farming system is dominated by crops grown under a discontinuous cover of scattered trees that constitutes the so-called parklands. Parklands are considered to be agroforestry systems, but their biodiversity depends on the original vegetation cover, the number and type of trees and shrubs spared during conversion to farmland, the needs of farmers, etc. [20]. Subsistence production includes the cultivation of cereals (such as sorghum, sesame, maize and millet) and tubers (yam and sweet potatoes) and animal husbandry. In addition to the above, a more complex and lucrative production system exists that involves the extraction of fuel wood and non-timber forest products, the cultivation of cash crops (cotton and fruit-tree plantations) and ranching [20]. The natural flora is dominated by perennial grasses such as Andropogon gayanus Kunth, A. ascinodis C.B. Clarke, and Schizachyrium sanguineum (Retz.) Alston [28]. Tree species commonly found in the parklands include Vitellaria paradoxa C. F. Gaertn, Parkia biglobosa (Jacq.) R. Br. ex G. Don., and Tamarindus indica L., amongst others. Forests in the study villages are under one of two management regimes: protected and classified forest. The classified forests, or national parks, ( 25 percent) are strictly protected from livestock and farming activities, 
while the protected forests (chantiers d'aménagements forestiers-CAF and forêts villageoises) are subject to field expansion and managed by local communities in collaboration with the government [14].

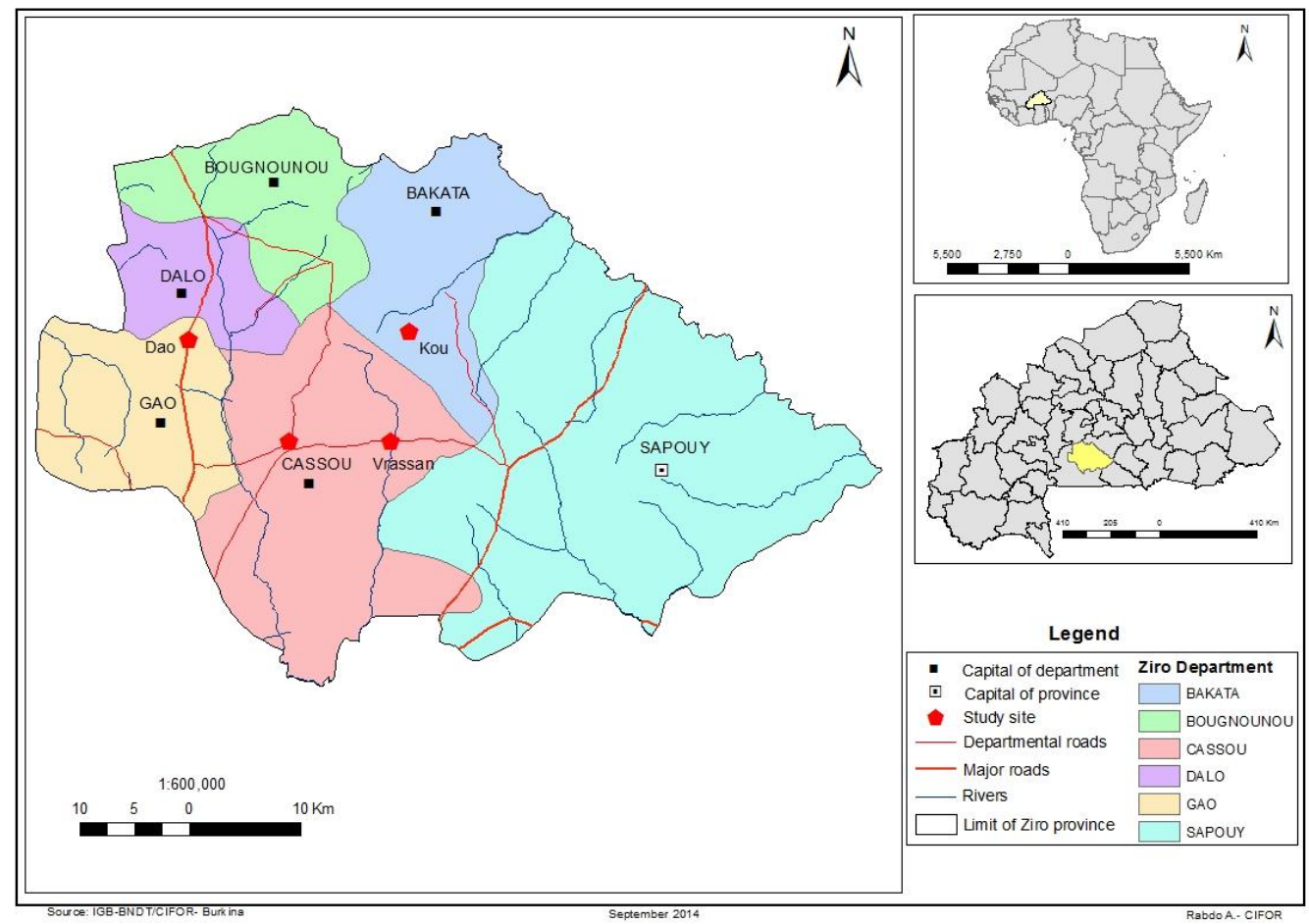

Figure 1. Study area.

\subsection{Sampling and Data Collection}

The first step of field data collection consisted of constructing a participatory poverty assessment (PPA) based on local indicators developed during a focus group discussion (FGD) in each of the four villages. Although approximately 70 percent of the population in Burkina Faso is rural and supported by the informal economy, national poverty assessment is based on income criteria [21]. Use of the money metric criterion $[29,30]$ in such rural communities as in Burkina Faso is misleading and is not the most adequate and applicable means for assessing poverty. Such a criterion is more applicable in urban areas where it is possible to assess income and expenditures using money as the unit of assessment. This is not the case in rural areas where banks are not available for money to be deposited, and which are dominated by an informal economy where wealth is stored in the form of assets. In rural areas, the informal economy sustains the livelihoods of households through natural resource and land-based economic activities such as farming, logging, trade, etc. This rural informal sector is highly complex and often rooted in traditional resources and land rights [31]. Therefore, the livelihood approach for assessing a household's wealth in relation to its asset holdings has been widely applied in rural developing countries [32]. In this approach, the real assets of a household are the unit of measurement, not money.

A total of five participants, including two women and three men from each of the three ethnic groups, participated in each FGD. The aim of the FGDs was to develop a poverty profile for the study area through a participatory exercise and to identify indicators of environmental degradation. The participants of the FGDs had to satisfy two conditions. Participants had to have lived in the community in or before 2003, which coincides with the start of the period used by the study for assessing deforestation. This time period is considered to be sufficiently long enough for the participants to know the level of well-being of other households. Participants were selected to represent a cross-section of the community in characteristics such as gender, ethnicity, wealth status, and neighborhood. Based on these criteria, participants were selected from among all the 'sub-chiefs' 
and women leaders of farmer management groups. This is because in Cassou, for example, the Mossi and Fulani ethnic groups live in separate quarters from the indigenous ethnic group (Gourounsi). Each of the ethnic groups has a leader, or sub-chief, who knows all the families in the village within that group. The women leaders were additionally selected because all the sub-chiefs were men.

Following Narayan et al. [33], the participants of each FGD were guided during the discussion to: (i) list local indicators used to assess wealth status in the community; and (ii) describe the specifications of each local indicator and its corresponding wealth category (see Table 1 for indicators). The resulting indicators differed slightly across the villages; therefore, the 20 participants of the four FGDs participated in a final meeting in Cassou to agree upon a common list (see the PPA below for more details). Participants also identified the following as environmentally degrading activities or indications of environmental degradation: field expansion (leading to deforestation), cotton cultivation, fuel wood exploitation, overgrazing, soil fertility loss, and local perceptions of tenure insecurity. Local participants identified tenure security as a factor playing a role in the adoption land management practices such as assisted natural regeneration. Tenure insecurity is likely to act as a disincentive for land management practices with long time horizons [25] compared to the use of practices such as composting, which are more immediately effective [34].

These outputs from the FGDs were reinforced with a literature review to locate corroborating scholarship on the activities identified by the FGDs as environmentally degrading in the region. These activities were found to be consistent with those identified in previous studies in Africa and Latin America $[6,15,35,36]$. A detailed questionnaire was then designed to collect both quantitative and qualitative data related to the environmentally degrading activities and which also addressed a specific set of land management practices (use of fallows, planting pits, composting, stone bunds, and live hedges) as well as household and farm characteristics (to be used for wealth categorization).

With the assistance of local youth leaders, 200 households from the study villages were randomly selected from a list of all households considered to fall within the different wealth status groups. Furthermore, 10 farms from each proposed wealth group were randomly selected for an additional farm survey, for a total of 30 farms. During the farm surveys, field sizes were estimated alongside other specific features of the farming systems such as fallows, evidence of assisted natural regeneration, live hedges, planting pits, stone bunds, use of compost, etc. The purpose of the farm survey was to confirm the interview questionnaire data.

\subsection{Analytical Methods: Categorizing Households Based on Local Indicators Derived from Participatory Poverty Assessment (PPA)}

As described above, participatory research methods were applied in which community members defined the wealth criteria based on local indicators [6]. Twelve wealth status indicators and their descriptions (Table 1) were identified during the FGDs. As a part of this process, participants selected a schema of wealth groups, with households categorized based on these indicators. A different set of wealth groups was identified in each study village, and three wealth groups were adopted for a common list. In Cassou, participants identified the groups: rich, fairly rich, poor, and poorest; in Dao and Kou: rich, fairly rich, and poor; and in Vrassan: rich and poor. To correct for these differences in income groups across locations, Ravnborg et al. [37] use a mean value, which was adopted in our study as follows: $(4+3+3+2) / 4=3$. Thus, the three income groups of non-poor, fairly poor and poorest were numbered 1,2 and 3 , respectively.

The next stage in this method was to transform the numbers to scores representing poverty levels. The qualitative rankings were quantified using the following equation adapted from Ravnborg et al. [37] as follows:

$$
\mathrm{S}=(\mathrm{A}-1) /(\mathrm{P}-1) \times 100
$$

where S = Well-being score; A = Income group of the household based on local perception of well-being indicators (Table 1); and $\mathrm{P}=$ the total number of wealth groups. The result was multiplied by 100 to avoid operating with decimals, resulting in: 
Level $1-[(1-1) /(3-1)] \times 100=0$, where 0 implies non-poor household

Level $2-[(2-1) /(3-1)] \times 100=50$, where 50 implies fairly poor household

Level $3-[(3-1) /(3-1)] \times 100=100$, where 100 implies poorest household

During the interviews, data were collected from each household based on the local indicators agreed upon in the common list (Table 1). In addition, data were collected on household resource management strategies self-reported by farmers, based on their perceptions, to capture activities considered environmentally degrading. Each household was assigned a corresponding score for all 12 indicators, which was later averaged by the first author to classify the household into its corresponding wealth group. The threshold values were then calculated to define the range of each wealth group based on the MEAN of all 200 household as follows: 0 to 50 (non-poor), 50 to 75 (fairly poor) and 75 to 100 for the poorest. Within these threshold values, it was possible to assign each individual mean to a category.

Table 1. Household poverty indicators and scoring system in southern Burkina Faso.

\begin{tabular}{|c|c|c|}
\hline Indicator & Score & Description \\
\hline Food security & $\begin{array}{c}0 \\
50 \\
100\end{array}$ & $\begin{array}{l}\text { Household without a period of food shortage in the last } 3 \text { years } \\
\text { Experienced a food shortage in the last } 3 \text { years that lasted }<3 \text { months } \\
\text { Experienced a food shortage in the last } 3 \text { years that lasted }>3 \text { months }\end{array}$ \\
\hline Healthcare & $\begin{array}{c}0 \\
50 \\
100\end{array}$ & $\begin{array}{l}\text { Capable of paying for the services of a doctor in the district hospital and beyond } \\
\text { Capable of paying for doctors' services limited to the district hospital } \\
\text { Household is unable to pay for a doctor's service and relies on herbal medicine }\end{array}$ \\
\hline $\begin{array}{l}\text { Nonagricultural } \\
\text { sources of income }\end{array}$ & $\begin{array}{c}0 \\
50 \\
100\end{array}$ & $\begin{array}{l}\text { Receives income from the sale of livestock, household shops, owns a truck } \\
\text { for transportation } \\
\text { Uses cart to transport crops for income, sells food and non-timber forest products } \\
\text { Household does not have any other source of nonagricultural income }\end{array}$ \\
\hline $\begin{array}{l}\text { Agricultural } \\
\text { equipment }\end{array}$ & $\begin{array}{c}0 \\
50 \\
100\end{array}$ & $\begin{array}{l}\text { Cultivates the land with tractor and draught ox, owns compost production facilities } \\
\text { Cultivates with donkeys and is capable of buying compost to use on farm } \\
\text { Cultivates the land with hand hoes and cutlasses }\end{array}$ \\
\hline Tree resources & $\begin{array}{c}0 \\
50 \\
100\end{array}$ & $\begin{array}{l}\text { Owns tree plantations (fruit trees, poles for construction, etc.) } \\
\text { Has a few trees on farm and around compound for subsistence and commercial use } \\
\text { Does not own trees on farm and compound but depends on the forest for NTFPs }\end{array}$ \\
\hline $\begin{array}{l}\text { Livestock } \\
\text { ownership }\end{array}$ & $\begin{array}{c}0 \\
50 \\
100\end{array}$ & $\begin{array}{l}\text { Owns three or more herds of cattle (a herd is } 10 \text { cows) } \\
\text { Owns less than three herds of cattle } \\
\text { Does not own any cattle }\end{array}$ \\
\hline Transportation & $\begin{array}{c}0 \\
50 \\
100\end{array}$ & $\begin{array}{l}\text { Owns } \geqslant 1 \text { car and } \geqslant 1 \text { motorcycle } \\
\text { Owns a motorcycle and a cart } \\
\text { Owns a bicycle and other members of the household often go on foot }\end{array}$ \\
\hline Institutional credit & $\begin{array}{c}0 \\
50 \\
100\end{array}$ & $\begin{array}{l}\text { Has the required collateral security for credit and is capable of paying back } \\
\text { Limited collateral for credit and might be unable to pay if externalities arises } \\
\text { Lacks collateral for credit and also lacks the potential for repayment }\end{array}$ \\
\hline
\end{tabular}

Note: NTFPs are goods obtained from the forests without harvesting whole trees.

\subsection{Study Variables Indicating Environmentally Degrading Activities}

The collected activities-related data were used to create variables of two kinds: numeric measurement-based variables and categorical variables (often self-reported). The former variables 
include mean annual deforestation (2003-2013), cotton cultivation, cutting and selling of fuel wood, and overgrazing based on cattle numbers. Categorical data were gathered through farmers' self-reported assessments on the following: overgrazing, soil fertility loss, and tenure security as an incentive for assisting natural regeneration. Overgrazing occurs in both categories because both numerical data and self-reported assessments of respondents were recorded. Several variables based on numeric measurement-based data were also converted to additional categorical variables for analyses (see below).

\subsubsection{Deforestation}

Through the interviews, data were collected on changes in farm area between 2003 and 2013. Farm size included areas under shifting cultivation with fallows. A recent study in Burkina Faso finds that farmers without fallows are more likely to expand their fields, thereby causing deforestation [38]. The lack of strict monitoring of community forest areas exposes them to encroachment. As such, field expansion into protected forest areas has been identified as the dominant proximate driver of deforestation in Burkina Faso [39,40]. In this study, the cultivation of fallows was not considered to represent deforestation because they represent potential areas for reuse when the rotation cycle is completed or as need arises. Therefore, deforestation in the current study focuses on the expansion of fields into protected forest.

$$
\text { Mean Annual Deforestation }=(\text { Farm Area in } 2013 \text { ha }- \text { Farm Area in } 2003 \text { ha }) / 10
$$

The difference in farm area was calculated as the change in farm area, excluding fallow, between 2013 and 2003. The result was divided by 10 to get the mean annual change value for the 10 -year-period. A categorical variable was created in addition to the continuous variable. Households that did not experience a change in farm area were assigned the value 0 , while those that cleared forests were assigned the value 1. Jones et al. [41], in an assessment of deforestation driven by farming systems, apply a mean annual area of forest cleared using this methodology. For additional details, see Etongo et al. [38]. Land is not for sale due to customary rules that prevail in these communities, thereby reducing the options for farm expansion.

\subsubsection{Cotton Cultivation}

Aside from the role of cotton as a driver of deforestation in Burkina Faso, where a threefold increase in cultivated area (ha) occurred between 1992 and 2007 [15], the use of pesticides also constitutes a threat to the environment [42]. An increase in the annual rate of pesticide consumption over the last two decades is attributed to the treatment of cotton fields [43]. The term pesticide covers a wide range of compounds including insecticides, fungicides, herbicides, etc. A pilot study in Burkina Faso on agricultural pesticide poisoning indicates its effect on the environment, livestock and human health [44]. This study employs both a continuous variable of cotton produced (in $\mathrm{kg}$ ) and a categorical variable for presence or absence of cotton cultivation at the farm level.

\subsubsection{Cutting and Selling of Fuel Wood}

Fuel wood is a major source of household energy in Burkina Faso and is collected from fields, fallows, forests, and plantations. The traditional measuring unit is a cart-driven system called a charet. A charet full of fuel wood is estimated at three $\mathrm{m}^{3}$. The estimated monthly fuel wood consumption per household in 2013 (for both subsistence use and sale) was recorded in charets and converted to cubic meters. A recent study in Burkina Faso estimates the average rural household's daily fuelwood consumption to be $0.04 \mathrm{~m}^{3}$ [45], which is roughly the same as estimated in Kenya [46]. Based on this daily estimate, monthly and annual consumption should stand at $1.24 \mathrm{~m}^{3}$ and $14.88 \mathrm{~m}^{3}$, respectively. These estimates provide a guide on household fuel consumption. In addition, information was collected on quantity of fuel wood sales and places of collection. This study employs both a continuous variable of reported monthly fuel wood consumption and a derived categorical variable which assumes fuel wood sales when reported monthly consumption was greater than $1.24 \mathrm{~m}^{3}$. 


\subsubsection{Overgrazing}

Average cattle herd sizes were collected for the last five years (2009-2013) to assess overgrazing in rangelands and farmlands. Studies on total livestock units (TLUs) in relation to stocking density consider overgrazing to occur when demand for fodder exceeds supply [18,47]. Niemeijer and Mazzucato [47] study total livestock units (TLUs) and arrive at a similar conclusion that overgrazing occurs when stocking density increases without an increase in fodder. Studies in the West African Sahel [19] and eastern Mediterranean [18] find that increases in livestock numbers are not consistent with fodder supply, thereby causing overgrazing. Furthermore, another study in Peru reports losses in range species as a consequence of high stocking rates, drought, and the absence of fallow areas [7]. In this study, the number of cattle was used as a continuous variable indicating overgrazing. In addition, a categorical variable was created using the mean value of 9.05 calculated among the 200 respondents, with two categories formulated as follows: households with $\leqslant 9$ cattle and households with $\geqslant 10$ cattle. Thus, owning more than the mean number of cattle was defined as indicative of overgrazing. To reinforce the above analysis, farmers also self-reported practices of overgrazing on their own farms in terms of environmental degradation as either low, moderate, and high.

\subsubsection{Farmers' Assessment of Tenure Insecurity on FMNR}

The role of indigenous tree species in remediating land degradation through farmer-managed natural regeneration (FMNR) is widely acknowledged in the Sahel $[48,49]$. FMNR fosters tree ownership and land tenure security for farmers. Also known as assisted natural regeneration, FMNR is the protection of indigenous tree species in the Sahel so that they can regenerate naturally to maturity [49]. It provides environmental benefits such as restoration of tree cover, increased biodiversity, climate change adaptation and mitigation, etc. [50]. In the interviews, farmers were asked if they participate in assisted natural regeneration. However, due to the sensitive nature of this line of questioning (as indigenous species are protected by law), this question was asked in the context of other questions to determine farmers' self-reported assessments of the state of natural regeneration of indigenous trees on their farms, who owns the trees, and how tenure security influences this practice. For this study, farmers' assessments of the role of tenure security for FMNR was used because these data were assessed to be the most accurate proxies for determining FMNR practice due to the sensitivity of the issue. Additionally, two studies in the Sahel indicated the importance of FMNR as a land management practice that improve tenure security and also tree cover on farms, thereby reducing environmental degradation [48,49].

\subsubsection{Farmers' Assessment of Soil Fertility Loss}

A study in Rwanda finds that local perceptions of soil fertility align well with soil fertility measured using local indicators such as crop yield, soil softness, indicator plants, and soil color [51]. Karltun et al. [52] also find consensus between farmers' indigenous knowledge and scientifically validated indicators of soil fertility. Using locally reported soil fertility thus is a viable alternative to direct or indirect measurement. Farmers' perceptions of soil fertility loss were adopted for this study and assessed at three levels: high, moderate and low. Three levels of soil fertility loss were adopted in the current study because this approach was found in Ethiopia to be effective when using perception-based methods [36].

\subsection{Statistical Analysis}

In order to compare the indicators of environmental degradation across the households in different wealth categories, we use descriptive statistics and non-parametric tests to analyze the data collected. Specifically, we applied Chi square to check the relationships between categorical variables. We use one-way ANOVA to compare the variation within the continuous variables across a single factor and determine whether significant differences existed among their means [53].

To run the ANOVA, Levene's test was used as a prior test for homogeneity of variance within the continuous variables. When a significant difference was found in the one-way ANOVA test at 
the 5 percent level, the Scheffe pairwise multiple comparison test was conducted for cases exhibiting homogenous variance [54]. For variables that exhibited non-homogenous variance, a Welch test was performed to correct the violation; then, Dunnett's C pairwise multiple comparison test was applied [55]. The multiple comparison tests highlighted where mean differences varied between pairs of wealth categories for the selected indicators.

\section{Results and Discussion}

\subsection{Poverty Level and Households' Characteristics}

Based on the results of the participatory poverty assessment (PPA) indicators, developed on the basis of local perceptions of poverty, 51.5 percent of the respondents were fairly poor, 32.5 percent were the poorest and 16 percent were non-poor (Figure 2).

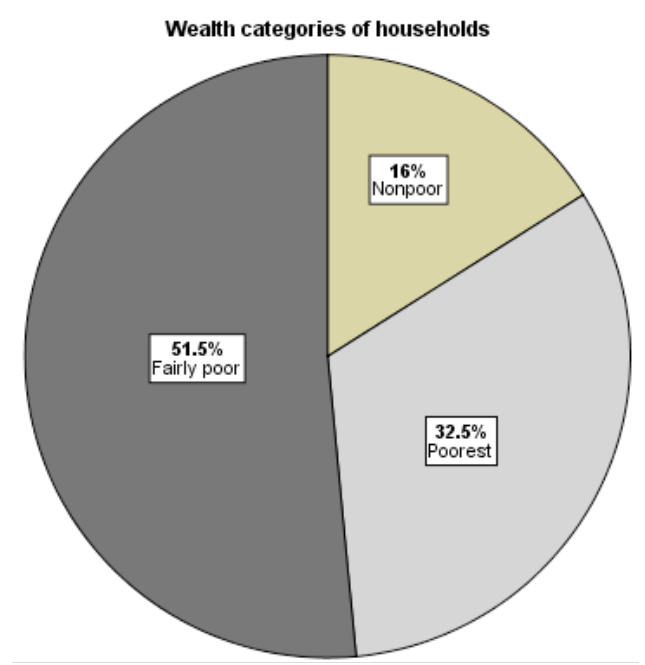

Figure 2. Percentage of farmers in each wealth category in the study area, across poverty levels $(\mathrm{N}=200)$.

The two hundred farm households interviewed were distributed among the Gourounsi, Mossi and Fulani ethnic groups as 46 percent, 41.5 percent and 12.5 percent, respectively (Table 2). A majority of the non-poor farmers belonged to the Fulani ethnic group followed by the Mossi. None of the respondents from the indigenous group (Gourounsi) were considered non-poor.

Table 2. Cross-tabulation results for categorical variables ( $\mathrm{N}=200)$.

\begin{tabular}{|c|c|c|c|c|c|c|c|}
\hline \multirow{2}{*}{\multicolumn{2}{|c|}{ Households Characteristics }} & \multicolumn{3}{|c|}{ Wealth Categories of Households (\%) } & \multirow{2}{*}{ Total (\%) } & \multicolumn{2}{|c|}{ Chi-Square Tests } \\
\hline & & Non-Poor & Fairly Poor & Poorest & & Value & Asymp. Sig. (2-Sided) \\
\hline \multirow{3}{*}{ Ethnic group } & Gourounsi & 0.0 & 48.5 & 64.6 & 46.0 & \multirow{3}{*}{108.147} & \multirow{3}{*}{0.000} \\
\hline & Mossi & 34.4 & 47.6 & 35.4 & 41.5 & & \\
\hline & Fulani & 65.6 & 3.9 & 0.0 & 12.5 & & \\
\hline \multirow{2}{*}{ Level of education } & No & 96.9 & 78.6 & 87.7 & 84.5 & \multirow{2}{*}{6.947} & \multirow{2}{*}{0.031} \\
\hline & Education & 3.1 & 21.4 & 12.3 & 15.5 & & \\
\hline \multirow{2}{*}{ Perceived tenure security } & Insecure & 100.0 & 51.5 & 35.4 & 54.0 & \multirow{2}{*}{36.595} & \multirow{2}{*}{0.000} \\
\hline & Secure & 0.0 & 48.5 & 64.6 & 46.0 & & \\
\hline \multirow{2}{*}{ Number of cattle } & $\leqslant 9$ & 0.0 & 85.4 & 100.0 & 76.5 & \multirow{2}{*}{128.713} & \multirow{2}{*}{0.000} \\
\hline & $\geqslant 10$ & 100.0 & 14.6 & 0.0 & 23.5 & & \\
\hline
\end{tabular}

The dominant farming system in Burkina Faso is the crop-livestock system. Livestock constitutes an invaluable asset for household wealth. Non-poor farmers owned more cattle (partly by definition, as number of cattle was a factor for categorizing households into wealth groups) and some farmers had over 20 head of cattle. Although cattle herding was done by all ethnic groups, it remains the 
main agricultural activity of the Fulani group that originates from the north. In the FGDs, participants indicated that poor households that owned few cattle are more likely to sell livestock during periods of poor harvest, or for anticipated expenditures such as school fees for children, etc. This finding differs slightly from another study in which smallholders and poor farmers were more likely to sell land for immediate benefits [18].

The level of education of the household head is likely to influence their livelihood. Across the wealth categories, 96.9 percent (non-poor), 78.6 percent (fairly poor) and 87.7 percent (poorest) could not read or write and were considered to be illiterate. The respondents who could read and write (were literate) included 3.1 percent (non-poor), 21.4 percent (fairly poor) and 12.3 percent (poorest). The overall level of illiteracy was 84.5 percent, and only 15.5 percent of the respondents were literate, with some education (Table 2).

\subsection{Indicators of Environmental Degradation: Differences among Wealth Categories}

This section presents the descriptive statistics as well as the mean comparisons (one-way ANOVA) among the wealth categories for the four numerical indicators used to quantitatively identify environmental degradation. The results indicate that all of the four numeric indicators of environmental degradation showed a statistical difference at the 5 percent significance level among all wealth categories (Table 3). This implies that each wealth category exhibited a different mean for each indicator of environmental degradation considered in the analysis.

Table 3. Continuous variables indicating environmentally degrading activities: Descriptive statistics and mean comparison (one-way ANOVA) (N=200).

\begin{tabular}{|c|c|c|c|c|c|c|}
\hline \multirow{2}{*}{\multicolumn{2}{|c|}{ Variables }} & \multicolumn{3}{|c|}{ Descriptive statistics } & \multicolumn{2}{|c|}{ One-way ANOVA } \\
\hline & & $\mathbf{N}$ & Mean & Std. Deviation & $\mathbf{F}$ & Sig. \\
\hline \multirow{4}{*}{$\begin{array}{c}\text { Mean annual } \\
\text { deforestation (ha) }\end{array}$} & Non-poor & 32 & 0.353 & 0.379 & \multirow{4}{*}{4.50} & \multirow{4}{*}{0.012} \\
\hline & Fairly poor & 103 & 0.274 & 0.293 & & \\
\hline & Poorest & 65 & 0.175 & 0.228 & & \\
\hline & Total & 200 & 0.255 & 0.295 & & \\
\hline \multirow{4}{*}{$\begin{array}{l}\text { Quantity of cotton } \\
\text { produced }(\mathrm{kg})\end{array}$} & Non-poor & 32 & 90.313 & 210.230 & \multirow{4}{*}{3.70} & \multirow{4}{*}{0.027} \\
\hline & Fairly poor & 103 & 124.563 & 205.229 & & \\
\hline & Poorest & 65 & 47.692 & 102.313 & & \\
\hline & Total & 200 & 94.100 & 181.731 & & \\
\hline \multirow{4}{*}{$\begin{array}{l}\text { Monthly fuel wood } \\
\text { consumption }\left(\mathrm{m}^{3}\right)\end{array}$} & Non-poor & 32 & 2.281 & 1.039 & \multirow{4}{*}{20.60} & \multirow{4}{*}{0.000} \\
\hline & Fairly poor & 103 & 1.849 & 0.776 & & \\
\hline & Poorest & 65 & 1.315 & 0.429 & & \\
\hline & Total & 200 & 1.745 & 0.805 & & \\
\hline \multirow{4}{*}{$\begin{array}{l}\text { Overgrazing } \\
\text { expressed by the } \\
\text { number of cattle }\end{array}$} & Non-poor & 32 & 41.500 & 34.586 & \multirow{4}{*}{104.90} & \multirow{4}{*}{0.000} \\
\hline & Fairly poor & 103 & 4.282 & 3.197 & & \\
\hline & Poorest & 65 & 0.6462 & 0.694 & & \\
\hline & Total & 200 & 9.055 & 19.897 & & \\
\hline
\end{tabular}

In addition, categorical variable forms of these indicators were analyzed for association with each wealth category (Table 4). Other indicators expressed as categorical variables also were considered, including farmers' self-reported assessments of overgrazing, loss of soil fertility and tenure security (as an incentive for long-term investment in the land via FMNR for instance). Thus, the categorical format was used for all of the variables to measure their association to the wealth status. The indicator of overgrazing was assessed twice: first as a categorical variable stemming from prior classification (owning more than the mean number of cattle), and then according to farmers' self-reported assessments. 
Table 4. Activities perceived as environmentally degrading and their relation to wealth categories $(\mathrm{N}=200)$.

\begin{tabular}{|c|c|c|c|c|c|c|c|}
\hline \multirow{2}{*}{\multicolumn{2}{|c|}{$\begin{array}{c}\text { Indicators of Environmental } \\
\text { Degradation }\end{array}$}} & \multicolumn{3}{|c|}{ Wealth Categories of Households (\%) } & \multirow{2}{*}{$\begin{array}{l}\text { Total } \\
(\%)\end{array}$} & \multicolumn{2}{|c|}{ Chi-Square Tests } \\
\hline & & Non-poor & Fairly poor & Poorest & & Value & $\begin{array}{l}\text { Asymp. Sig. } \\
\text { (2-sided) }\end{array}$ \\
\hline \multicolumn{8}{|c|}{ Derived categorical forms from our quantitative collected variables } \\
\hline \multirow{2}{*}{ Deforestation 2003-2013 } & No & 1.00 & 19.50 & 16.50 & 37.00 & \multirow{2}{*}{18.30} & \multirow{2}{*}{0.000} \\
\hline & Yes & 15.00 & 32.00 & 16.00 & 63.00 & & \\
\hline \multirow{2}{*}{ Cotton cultivation } & No & 13.00 & 30.50 & 25.50 & 69.00 & \multirow{2}{*}{9.57} & \multirow{2}{*}{0.008} \\
\hline & Yes & 3.00 & 21.00 & 7.00 & 31.00 & & \\
\hline \multirow{2}{*}{$\begin{array}{l}\text { Cutting and selling } \\
\text { fuel wood }\end{array}$} & No & 14.50 & 27.00 & 19.50 & 61.00 & \multirow{2}{*}{15.01} & \multirow{2}{*}{0.001} \\
\hline & Yes & 1.50 & 24.50 & 13.00 & 39.00 & & \\
\hline \multirow{2}{*}{$\begin{array}{l}\text { Overgrazing based on } \\
\text { owning more than mean } \\
\text { number of cattle }\end{array}$} & No & 0.00 & 19.00 & 27.00 & 46.00 & \multirow{2}{*}{66.67} & \multirow{2}{*}{0.000} \\
\hline & Yes & 16.00 & 32.50 & 5.50 & 54.00 & & \\
\hline \multicolumn{8}{|c|}{ Variables collected in qualitative forms from field work } \\
\hline \multirow{3}{*}{$\begin{array}{l}\text { Overgrazing (farmers' } \\
\text { assessments of overgrazing } \\
\text { on their own farms) }\end{array}$} & Low & $0.0 \%$ & $42.7 \%$ & $84.6 \%$ & $49.5 \%$ & \multirow{3}{*}{110.259} & \multirow{3}{*}{0.000} \\
\hline & Moderate & $6.3 \%$ & $32.0 \%$ & $15.4 \%$ & $22.5 \%$ & & \\
\hline & High & $93.8 \%$ & $25.2 \%$ & $0.0 \%$ & $28.0 \%$ & & \\
\hline \multirow{3}{*}{$\begin{array}{l}\text { Soil fertility loss (farmers' } \\
\text { assessments of soil fertility } \\
\text { loss on their own farm) }\end{array}$} & Low & $65.6 \%$ & $49.5 \%$ & $27.7 \%$ & $45.0 \%$ & \multirow{3}{*}{42.191} & \multirow{3}{*}{0.000} \\
\hline & Moderate & $28.1 \%$ & $23.3 \%$ & $6.2 \%$ & $18.5 \%$ & & \\
\hline & High & $6.3 \%$ & $27.2 \%$ & $66.2 \%$ & $36.5 \%$ & & \\
\hline \multirow{2}{*}{$\begin{array}{l}\text { Tenure insecurity (farmers' } \\
\text { assessments of effect of } \\
\text { tenure insecurity on } \\
\text { farmer-managed } \\
\text { natural regeneration) }\end{array}$} & No FMNR & $100.0 \%$ & $51.5 \%$ & $35.4 \%$ & $54.0 \%$ & \multirow{2}{*}{36.595} & \multirow{2}{*}{0.000} \\
\hline & Yes FMNR & $0.0 \%$ & $48.5 \%$ & $64.6 \%$ & $46.0 \%$ & & \\
\hline
\end{tabular}

\subsubsection{Deforestation}

Sixty-three percent of respondents expanded their fields into forests or cleared new farmland between the years 2003 and 2013, while 37 percent did not (Table 4). Furthermore, the non-poor farmers caused more deforestation than the poorest, with the difference in the changes in farm area during the 10-year period significant at the 5 percent level (Table A1). These findings are contrary to the poverty-induced environmental degradation that is considered to be driven primarily by the poor [1,2]. Some studies show that the poor are not so obsessed with their present and short-term nutritional needs that they completely ignore long-term livelihood security and resource productivity concerns $[6,7,9,10]$. Instead, poverty constrains farm households from adopting land management practices considered to be sustainable and thereby further intensifies land degradation.

\subsubsection{Cotton Cultivation as an Environmentally Degrading Activity}

Thirty-one percent of respondents cultivated cotton, while 69 percent did not (Table 4). Cotton cultivation is likely to follow the same pattern for fairly-poor and non-poor farmers, as there is no statistical difference between these two groups. Notwithstanding, significant differences were identified between the fairly-poor and poorest farmers (Table A2). This implies that the fairly poor and non-poor produced relatively higher quantities of cotton as a result of larger farm areas under cultivation and contributed more to environmental degradation than the poorest. Cotton cultivation in Burkina Faso requires animal traction and the use of pesticides and is capital intensive [15], which limits the participation of the poorest farmers. According to Ton [56], the expansion of cotton production in West Africa has been driven by households equipped with animal traction, and those with manual tools have been unable to participate effectively in this livelihood activity. Other studies in Burkina 
Faso determine that cotton cultivation is a driver of deforestation $[14,15,57,58]$. Here, the resultant pesticide contamination is additionally considered.

Agricultural poisoning was identified as a common problem in the region and attributed to the use of pesticides for the treatment of cotton. During one of our field visits in Vrassan village in January 2014, approximately eight cattle were found dead and many more affected (see Figure 3). A report from the district veterinary officer indicated that the cattle had been poisoned by eating fodder from a field that had been treated by herbicides used in cotton cultivation. Other studies in Burkina Faso identify similar cases in which cotton treatment resulted in agricultural poisoning that affected not only livestock but also human life [43,44].
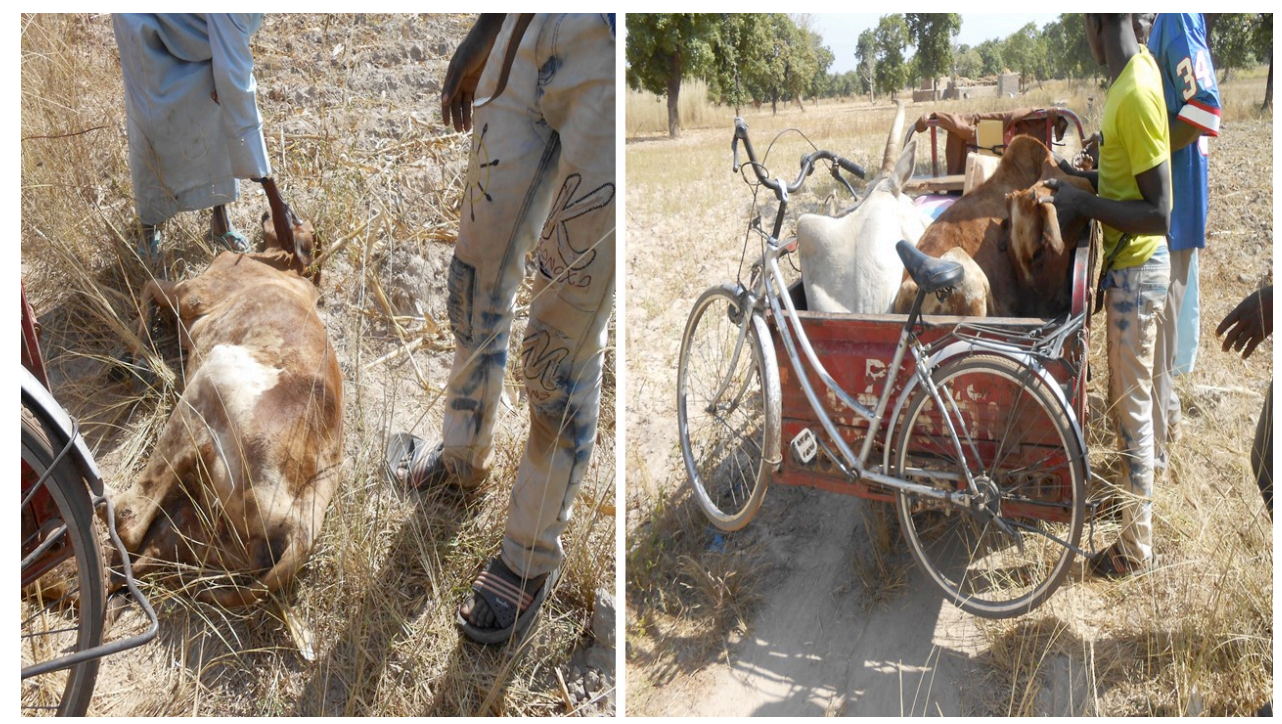

Figure 3. Cattle suffering from agricultural poisoning emanating from cotton treatment in Vrassan village.

\subsubsection{Cutting and Selling Fuel Wood}

Sixty-one percent of households did not cut and sell fuel wood, compared to the 39 percent who engaged in this activity (Table 4). Comparisons among wealth categories indicated that the non-poor cut and sell larger quantities of fuel wood than the fairly-poor and poorest households. Likewise, fairly-poor farmers cut and sell more fuel wood than the poorest (Table A2). Thus, the relative contributions of non-poor and fairly-poor farmers to environmental degradation are higher than that of the poorest. The cutting of fuel wood in Burkina Faso is dominated by the use of rudimentary tools such as axe heads, which require the availability of some household work force, the potential to hire labor and the ability to provide better means of transportation.

Cutting and selling fuel wood in Burkina Faso is quickly degrading the environment and over 85 percent of urban and rural populations depend on wood fuel (fuel wood and charcoal) to supply household energy [13]. The increasing demand for fuel wood has led to illegal exploitation and unsustainable harvesting that does not allow sufficient time for regrowth and thereby affects wood volume. The poorest households cannot effectively benefit from this source of off-farm employment in the region. As such, poverty as a state of deprivation appears to reduce the chances that the poorest in the society engage in certain resource management strategies considered to be environmentally degrading [35]. The view corroborate our findings in which the poorest household equipped with relatively little resources (income to hire labor and pay for transportation) limits the extraction of wood from the forests.

\subsubsection{Overgrazing}

The assessment of overgrazing on their own farms (Table 4) showed that 84.6 percent of the poorest households perceive themselves as experiencing a low level of overgrazing. This self-perception is 
not different from our assessment based on the number of cattle owned because we found that the poorest were mostly associated with lower numbers of cattle. This indicator was significantly higher for the non-poor and fairly poor at a 5 percent level of significance (Table A2). Furthermore, 15.4 percent of households in the poorest category reported a moderate level of overgrazing, and none of them perceived themselves as experiencing high rates of overgrazing (Table 4). Finally, the fairly poor and the non-poor see themselves as experiencing high level of overgrazing (25.2 percent and 93.8 percent, respectively). These findings likely reflect the non-poor owning larger herds of cattle, which increases demand for fodder and likely causes higher rates of overgrazing. During the FGDs, the Fulani ethnic group was identified as owning large herds of cattle more often than the Mossi and Gourounsi ethnic groups. Increases in livestock number and a reduction in rangeland through land fragmentation have been identified as a threat to important fodder trees such as Afzelia africana and Pterocarpus erinaceus [19].

\subsubsection{Perceptions of Soil Fertility Loss}

A majority of the households reporting soil fertility loss were the poorest farmers, followed by the fairly poor. On the other hand, only 6.3 percent of the non-poor farmers perceived high rates of soil fertility loss (Table 4). Without inputs in the form of fertilizers and the application of land management techniques, soil fertility typically decreases over time. A study conducted in Ethiopia observes declines in soil fertility amongst farm households over time [36]. The lower rates of perceived soil fertility loss amongst the non-poor and fairly-poor farmers may be due to the greater availability of resources for improving the land, for the non-poor and fairly poor in comparison to the poor.

Loss of soil fertility continues to be a major problem that affects agricultural activities in different parts of the world, reducing productivity and in some cases causing crop failure [59,60]. Although considered to be a common problem, farmers' self-reported soil fertility loss is perceived by researchers to affect households differently. This is because knowledge and experience in soil conservation practices varies among different income and social groups within a community [61], a pattern that is consistent in our findings. Furthermore, impacts on farm households can depend on individual elements in the ecosystem that buffer the effects of anthropogenic and natural disturbances [62].

\subsubsection{Farmers' Assessment of Tenure Insecurity on Assisted Natural Regeneration}

Results show that many non-poor (100 percent), fairly poor (51.5 percent), and poorest (35.4 percent) households perceive their land tenure to be insecure (Table 2). Though these figures are much higher for the fairly-poor farmers (compared to the poorest ones), all the non-poor perceive their own tenure to be insecure (Table 2). Within the context of rural Burkina Faso, rights of limited use are often granted to migrants, while the indigenous groups are granted permanent use rights through inheritance. Land chiefs assign a portion of land to migrants without receiving monetary compensation, and the conditions that govern these land rights are uncertain. Ouédraogo [63] finds that land tenure types in Burkina Faso include: (i) rights of permanent use granted to the indigenous group; (ii) rights of permanent use acquired by claiming unclaimed forested land; (iii) rights of limited use extended to the indigenous group that might become permanent if held for more than one generation; (iv) rights of limited use granted to "strangers" (non-indigenous people) who are considered borrowers of the land. The first three tenure types are associated with indigenous groups, while migrant groups only have limited use rights. Farmers occupying borrowed lands are less likely to participate in FMNR because they lack a full bundle of rights to the land and trees including the right of transfer [63]. However, longer periods of management (approximately 30-40 years) give them some degree of ownership, especially if the land has been improved [39]. Despite these farmers' perceived sense of ownership, the indigenous population considers land occupied by migrants as borrowed. This is because land allocation is not linked to cash transfers, although borrowers do show gratitude through gifts.

Although rights of limited use are granted to migrants, without violation of local rules they can occupy such land as long as desired. One local rule is that they are not allowed to plant economic trees 
without permission from the land chiefs. Traditionally, loaned lands were not withdrawn unless there was a serious violation of rules of conduct. However, as land reserves are becoming exhausted in the southern region of the country, some cases of withdrawal without violation of local laws have been identified. This finding is consistent with an earlier study in Burkina Faso where land withdrawal occurred without violation of local laws [64]. As a result, perceptions of tenure security may be changing for borrowed lands, as supported by our findings here.

Based on farmers' self-reported assessments, the entire non-poor group reported that their own insecure tenure affected their practice of assisting the natural regeneration of trees on farms, as did 51.5 percent of the fairly poor and 35.4 percent of the poorest (Table 4). Farmers with insecure tenure are likely not to carry out long-term investments such as fallows, assisted natural regeneration of trees, etc. to improve the land. Thus, in-migrants (with insecure tenure due to their status as land borrowers) are hesitant to participate in long-term land management strategies.

However, FMNR is widely promoted in the Sahel because it has proven to foster tree ownership and land tenure security for farmers. Furthermore, it provides numerous environmental benefits such as restoration of tree cover, increased biodiversity that increases resilience to climate change, etc. Studies in Burkina Faso [65] and the Sahel [48,49] acknowledge the importance of FMNR in addressing desertification and land degradation while providing economic benefits to farmers. Farmers engaged in assisting natural regeneration contribute less to environmental degradation than they would in the absence of this activity. Thus, tenure security is an incentive for FMNR, a finding consistent with a previous meta-analysis conducted in tropical developing countries [66].

\subsection{Land Management Practices Adopted by Respondents}

Five common land management practices in the study area were investigated to assess whether poverty constrains the adoption of practices considered to protect the environment. These practices included fallowing, construction of planting pits, composting, use of stone bunds and use of live hedges (Figure 4).
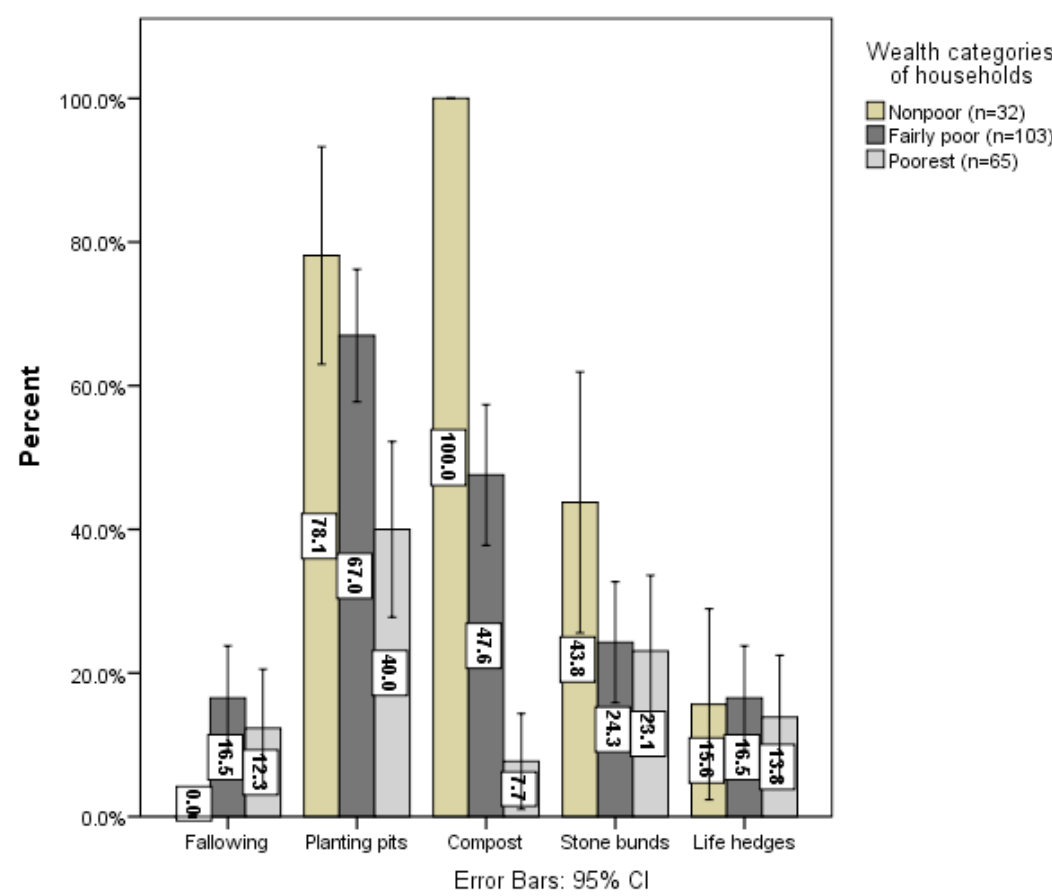

Figure 4. Land management practices adopted by respondents across poverty levels $(\mathrm{N}=200)$.

\subsubsection{Fallows}

None of the non-poor farmers reported having fallow areas. On the other hand, 16.5 percent of the fairly-poor and 12.3 percent of the poorest farmers practiced fallowing. Improved fallow areas are 
considered to be a low-cost practice for improving soil fertility in the Sahel. This is made possible by a variety of tree species that regenerate naturally in the study area such as Parkia biglobosa, Vitellaria paradoxa, etc. Because migrant status is a proxy for insecure tenure to land and trees, the migrant-status of the non-poor may explain why no respondents in this group practiced fallowing. Aside from soil fertility improvement, fallows are used for other purposes as well, as sources of fuel wood, fodder, etc. Due to low inputs in agriculture in the study area, farmers without fallows are more likely to expand their fields into forest areas in order to increase production. Thus, fallows are important for both soil fertility improvement and livelihood value, a premise consistent with several past studies conducted in the West African Sahel $[67,68]$.

\subsubsection{Planting Pits}

Also known as zaï, a planting pit is a soil water conservation technique commonly practiced in the Sahel. The percent of respondents who adopted this practice was lowest among the poorest (40 percent), compared to the non-poor (78.1 percent) and fairly poor (67 percent), for whom the use rates were relatively high. Zaï practice is labor intensive, and a household work force or the ability to hire labor is a prerequisite for its adoption. Two previous studies in Burkina Faso estimated that installing zaï on a hectare of land requires six to twelve weeks of daily work for one person, depending on soil condition $[69,70]$.

Despite the labor demand, zaï is a critical practice in Burkina Faso due to the effects of climate variability and change on food security and livelihoods. Participants in the FGDs indicated that water harvested through this technique contributes to assisting natural regeneration in less than four years. An earlier study in Burkina Faso finds that zaï practice rehabilitates land within three to five years [71].

\subsubsection{Composting}

Results show that the respondents who apply compost on their farms include non-poor (100 percent), fairly-poor ( 47.6 percent) and poorest farmers (7.7 percent) (Figure 4$)$. The FGDs revealed that although compost on fields is known to improve soil fertility, its adoption is dependent on the resources available to farmers. Studies in Burkina Faso [60,69] and the Sahel [62] acknowledge the importance of compost for soil fertility improvement. Compostable material such as crop residues have to be transported to a compost pit and then crushed with additives to produce compost (Figure 5). To construct and maintain such facilities requires money that the poorest farmers cannot afford. During the FGDs it was indicated that the poorest households are more likely than others to make use of community compost facilities. Due to the large time requirement for producing compost (2-3 months), those who use the community facilities have to work together to produce compost and then share it.
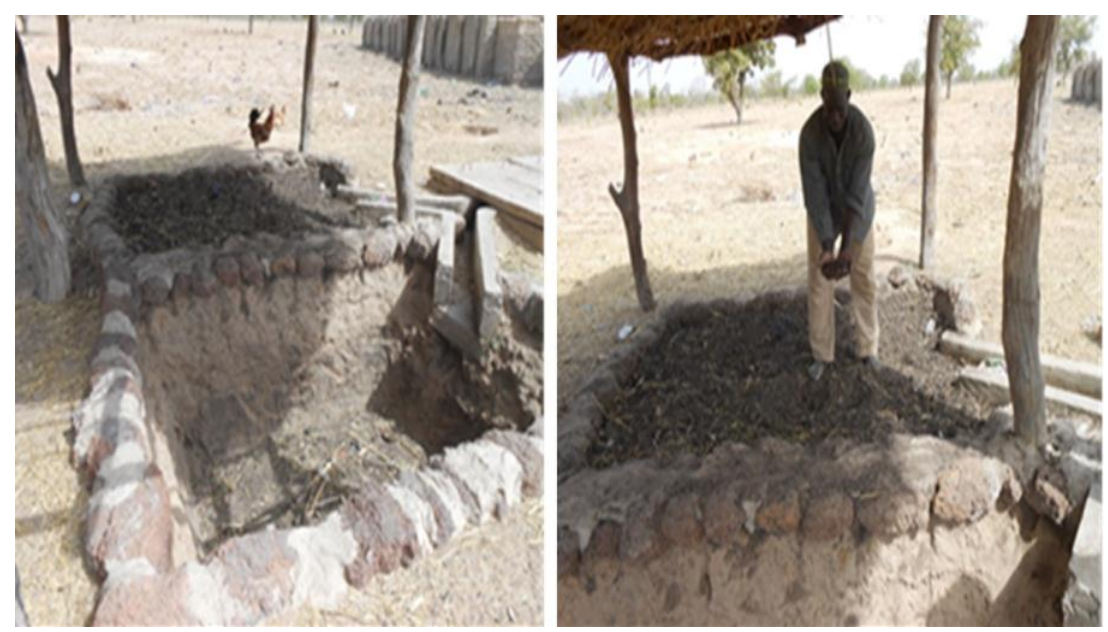

Figure 5. A compost facility owned by a household in Kou Village. 
Most of the non-poor farmers belong to the Fulani ethnic group who own larger herds of cattle than other wealth categories. The dung from these cattle is vital in producing compost. As such, the household socioeconomic characteristics of farmers are important for adopting this technology and often constrain poor farmers with little resources at their disposal. A study in Burkina Faso finds that socioeconomic factors affect the adoption of compost technology in favor of households with greater available resources [69].

\subsubsection{Stone Bunds}

The respondents who adopted stone bunds across the wealth categories included non-poor (43.8 percent), fairly-poor ( 24.3 percent) and poorest farmers (23.1 percent). Among the fairly poor and poorest farmers, the adoption rates for stone bunds were similar, while for the non-poor farmers it was relatively high. Stone bunds are a soil conservation technique that involves the laying of stones on fields (Figure 6) to check runoff and to control soil erosion. This technique traps soil and allows it to accumulate over time. Another study in Burkina Faso indicates that although soil properties did not change significantly over a five-year period due to stone bunds, there was an increase in depth of the top layer of soil [70]. Farmers who have stones on their farms need to transport them to areas within the farm where the bunds are to be constructed. In the absence of available stones on farmland, households that want to engage in this practice must transport the stones from outside.

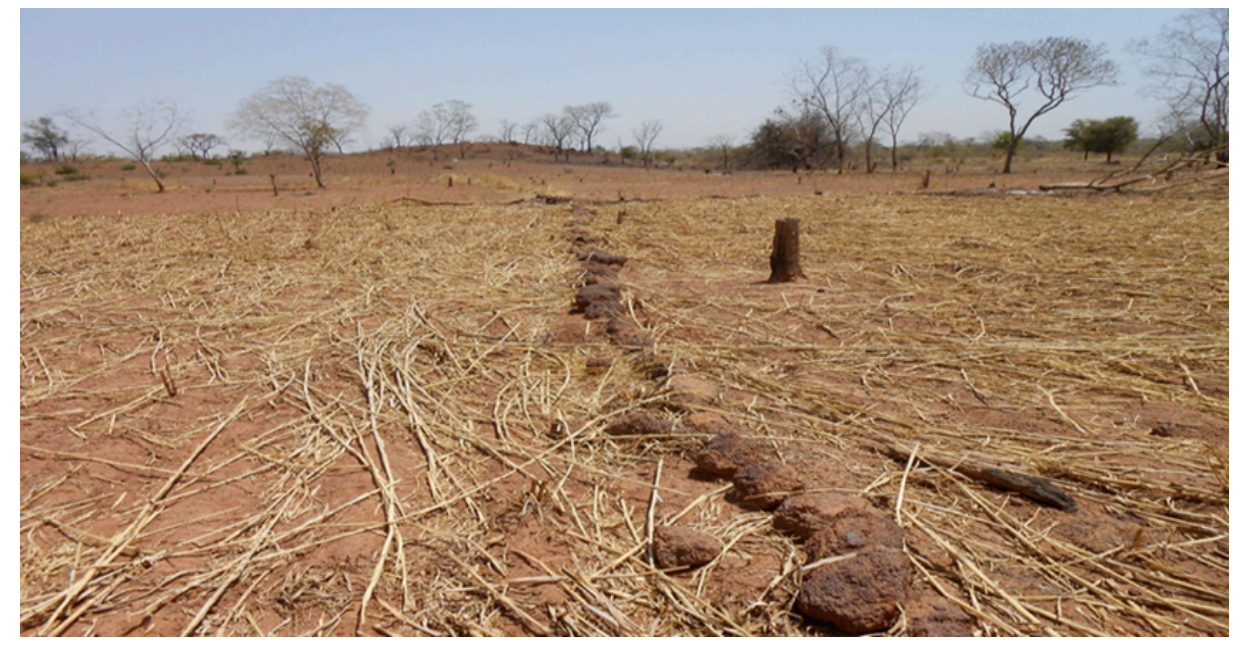

Figure 6. Use of stone bunds on farmland in Vrassan Village.

\subsubsection{Live Hedges}

The poorest farmers had the lowest percentage of adopters (13.8 percent) of live hedges on their farms. Among the fairly-poor farmers, 16.5 percent adopted this practice, and for the non-poor, the adoption rate was 15.6 percent. Live hedges are also known as living fences and are created by the planting of trees on part or all of the farm boundaries (see Figure 7). This practice provides a buffer against wind and water erosion. Two studies in Burkina Faso also report that dense tree cover buffer the effects of wind [72] and rainfall [73] and in turn reduce soil erosion. The relatively low adoption rates amongst the non-poor could be related to findings that all farmers in this wealth category perceived their own tenure to land and trees to be insecure. Aside from reducing the intensity of soil erosion, live hedges are important sources of fodder and fuel wood. Therefore, live hedges provide both livelihood benefits and environmental benefits to farmers. 


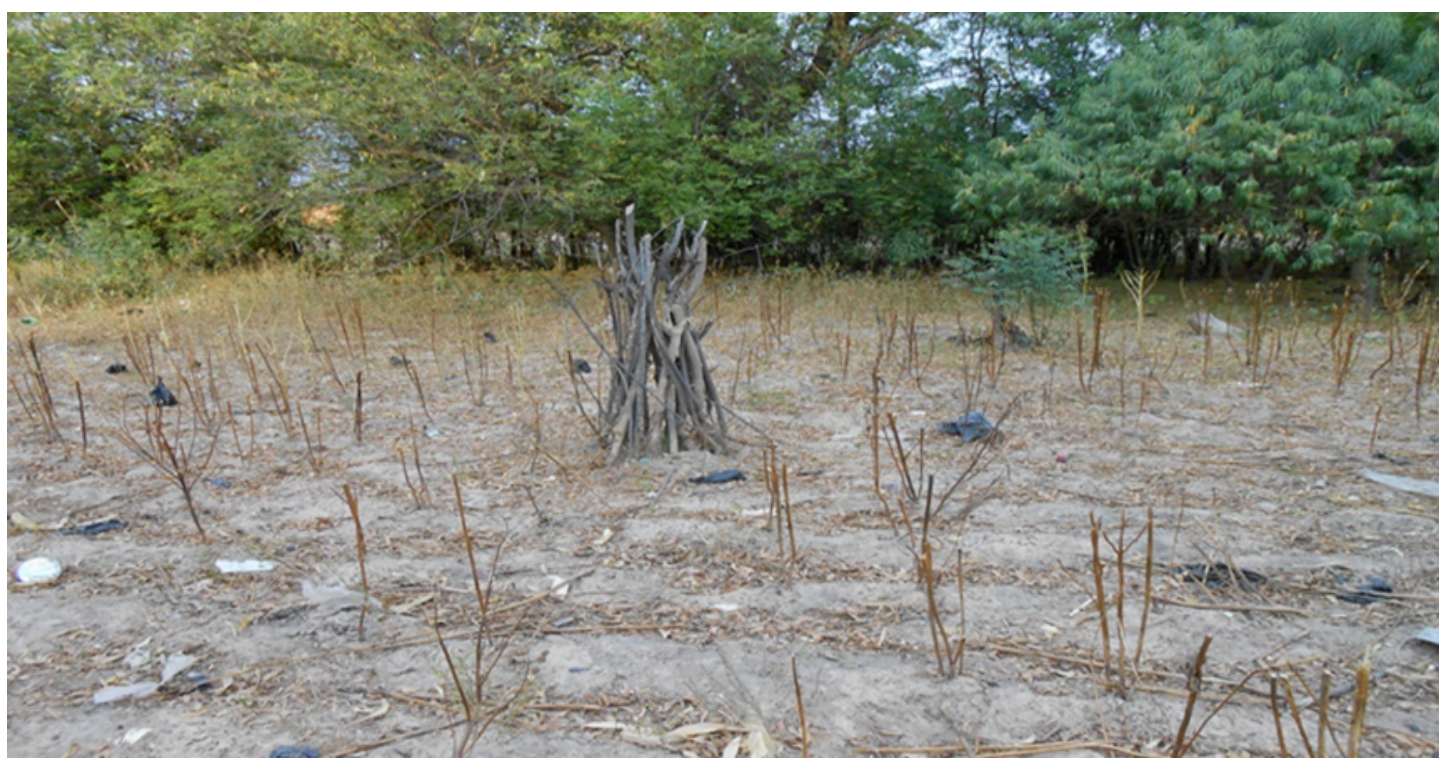

Figure 7. Live hedge in Cassou Village with Azadirachta indica.

\section{Limitations}

This study faces several limitations. First, as part of the process of grouping households into different wealth status categories, one of the roles of the FGDs was to identify every household in each category. With a total of 900 households in the four villages, having detailed information for all households was challenging. To overcome this limitation, the twenty participants from the four villages agreed on a common list of local indicators to use in categorizing the households. The researchers then collected interview data from households based on these indicators and later classified households into different categories of wealth. Thus, the PPA approach could only be implemented in a limited way. However, the study maintained the key aspect of participant input into how poverty was defined.

In addition to limitations arising from the application of the PPA, the use of PPA itself introduced a key limitation into the study's analytical methods and findings. Both the number of cattle and the amount of land held by a household were used as independent variables in the categorization of households into the wealth groups. The use of these variables in wealth categorization is a direct reflection of local definitions of household wealth and a function of the PPA process. However, these variables also play a key role in the analysis of household engagement in environmentally degrading activities. The study treated number of cattle as a dependent variable to assess overgrazing. Furthermore, several of the environmental degradation dependent variables logically correlate with farm size: annual mean deforestation, as measured in hectares, likely reflects farm size, as does cotton production in kilograms. We nonetheless consider our findings to have merit, precisely because they highlight the role of wealth, as defined locally, as a driving force in environmentally degrading activities at this research site.

Next, self-reported assessments by farmers can be biased, especially if the issue under investigation is considered sensitive. Such data can only be gathered indirectly because a direct question might be too sensitive and can affect the engagement of respondents. Because parkland tree species are protected by law, farmers are likely not to provide information if such species are fast degrading on their farmlands. Also, unequal and small sample sizes might not effectively reveal differences between groups. Finally, applying a unified list of indicators across multiple villages requires careful consideration of potential differences in the socio-cultural settings. In our case, it was easier because these villages are close to each other and share ethnicity and culture. 


\section{Conclusions}

This case study of the poverty-environment nexus not only reveals that the relationship between wealth or poverty status and environmentally degrading activities is site specific in general, as well as activity specific; it also provides insights into resource management practices across different wealth groups at this site. The current study reveals that non-poor and fairly poor farmers engaged more often in environmentally degrading activities compared to the poorest farmers. Approximately 93 percent of non-poor and 22 percent of fairly-poor farmers experienced high rates of overgrazing, while none of the poorest farmers experienced high rates of overgrazing. This is because the non-poor and fairly-poor farmers possess the available resources to own large herds of cattle. This study in fact categorized households into wealth status groups in part based upon number of cattle owned. Equipped with capital, the non-poor and fairly-poor farmers engaged more effectively in the cutting and selling of fuel wood and cotton cultivation than did the poorest farmers. Based on farmers' self-reported assessment of the role of their tenure security in relation to assisting natural regeneration of indigenous tree species, tenure insecurity constitutes a major constraint on FMNR. FMNR is known to reduce environmental degradation, and due to their perceived inability to participate in this practice, the non-poor contribute more to environmental degradation. Parklands in the Sahel have existed for centuries because of the regeneration of indigenous tree species that provide multiple livelihood and environmental benefits.

Furthermore, deforestation through field expansion proved to be significant for the fairly-poor and non-poor households. Cotton cultivation, which can motivate field expansion and lead to heavy pesticide use, is capital intensive. The lack of available resources among the poorest farmer limits their effective participation in this practice. Other activities considered environmentally degrading, such as the cutting and selling of fuel wood, are dominated by the fairly poor and non-poor farmers.

On the other hand, self-reported assessment of soil fertility loss was highest among the poorest farmers. In addition, the adoption rates of land management practices considered to improve the land (and help ameliorate soil fertility loss) were relatively low for the poorest households. Some of these land management practices, e.g. planting pits, use of compost and stone bunds, are both labor and capital intensive, which may explain the low rates of adoption among the poorest farmers.

Therefore, the results of our study indicate that the non-poor and fairly-poor farmers contribute toward environmentally degrading activities relatively more, while poverty constrains the adoption of sustainable land management practices for the poorest farmers. Further research is needed in the following areas: (i) a comparison of natural resource management strategies for in-migrant farmers versus indigenous farmers; (ii) the relationship among ethnicity, poverty, and environmental degradation; (iii) the role of tenure security, land quality, and land fragmentation on sustainable land management; and (iv) the factors influencing FMNR in Burkina Faso.

Acknowledgments: This work was supported by WP3 (National Policies and Capacity Strengthening) of the Building Biocarbon and Rural Development in West Africa Project (BIODEV) funded by the Ministry of Foreign Affairs of Finland. We also thank the International Tropical Timber Organization (ITTO) for providing funding for this research. We thank Oumarou Bognini for his assistance during the field work and the people of the local communities who developed the local indicators for poverty. We are thankful to Mr. Rabdo Abdoulay for producing a map for the study area.

Author Contributions: Daniel Etongo conceived the paper rationale and carried out data collection. Daniel Etongo and Nadia Djenontin analyzed the data. Daniel Etongo wrote the general draft and Nadia Djenontin and Markku Kanninen edited and contributed to the interpretation of results and discussion. All authors participated in the final draft.

Conflicts of Interest: The authors declare no conflict of interest. 


\section{Appendix}

Table A1. Multiple comparison Scheffe Test for variables for which homogeneity of variance is assumed $(\mathrm{N}=200)$.

\begin{tabular}{|c|c|c|c|c|c|c|c|}
\hline \multirow{2}{*}{\multicolumn{3}{|c|}{ Dependent Variable }} & \multirow{2}{*}{$\begin{array}{c}\text { Mean Difference } \\
\text { (I-J) }\end{array}$} & \multirow{2}{*}{ Std. Error } & \multirow{2}{*}{ Sig. } & \multicolumn{2}{|c|}{ 95\% Confidence Interval } \\
\hline & & & & & & Lower Bound & Upper Bound \\
\hline \multirow{6}{*}{$\begin{array}{c}\text { Annual average } \\
\text { deforestation }\end{array}$} & \multirow{2}{*}{ Non-poor } & Fairly poor & 0.08 & 0.06 & 0.40 & -0.07 & 0.22 \\
\hline & & Poorest & $0.17 *$ & 0.06 & 0.01 & 0.02 & 0.33 \\
\hline & \multirow{2}{*}{ Fairly poor } & Non-poor & -0.08 & 0.06 & 0.40 & -0.22 & 0.06 \\
\hline & & Poorest & 0.09 & 0.05 & 0.10 & -0.01 & 0.21 \\
\hline & \multirow{2}{*}{ Poorest } & Non-poor & $-0.17 *$ & 0.06 & 0.01 & -0.33 & -0.02 \\
\hline & & Fairly poor & -0.09 & 0.05 & 0.10 & -0.21 & 0.01 \\
\hline
\end{tabular}

* The mean difference is significant at the 0.05 level.

Table A2. Multiple comparison Scheffe Test for variables for which homogeneity of variance is not assumed $(\mathrm{N}=200)$.

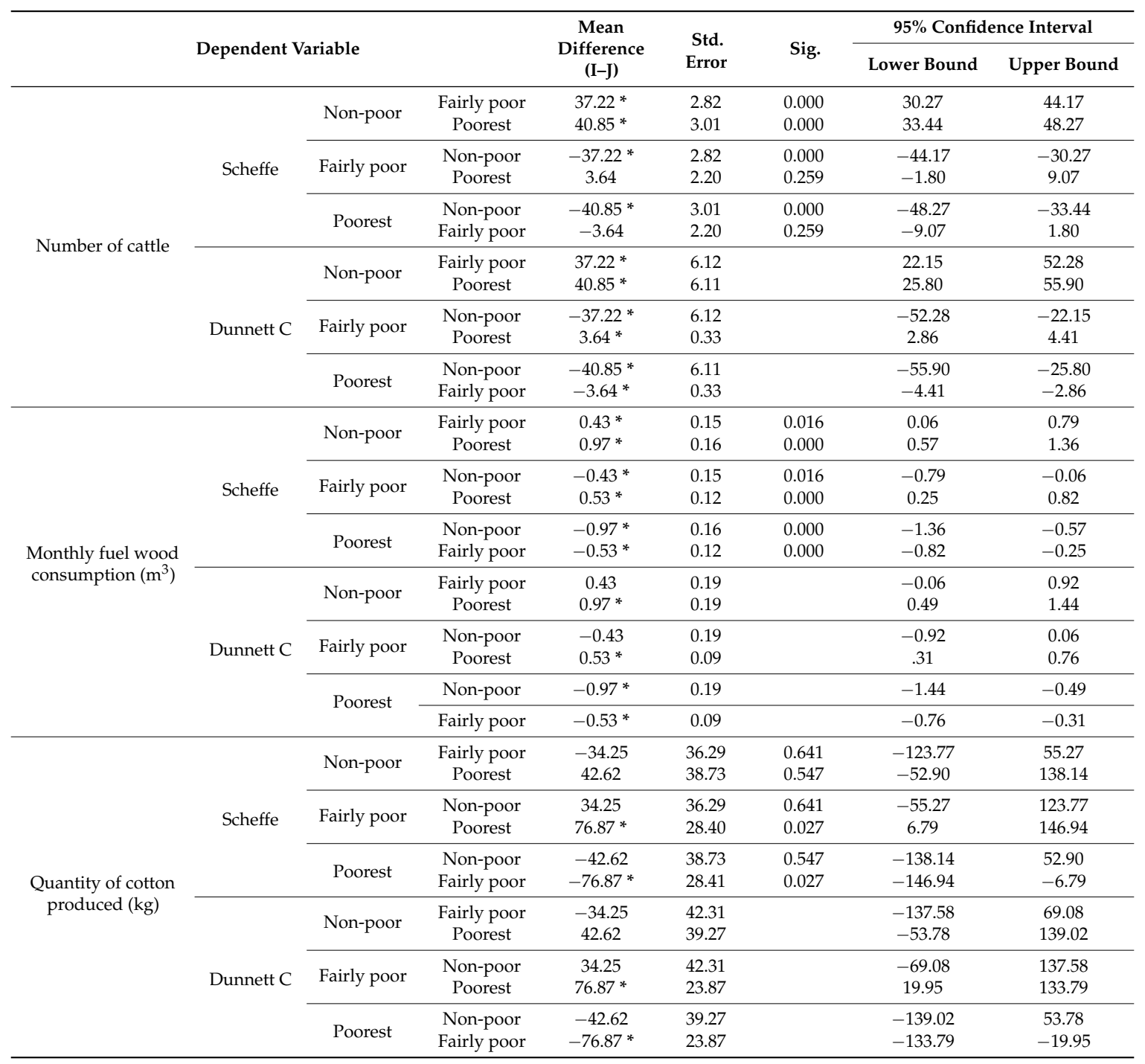

* The mean difference is significant at the 0.05 level. 


\section{References}

1. Bojö, J.; Bucknall, J.; Hamilton, K.; Kishor, N.; Kraus, C.; Pillai, P. Environment Chapter, Poverty Reduction Strategy Papers' Source Book; World Bank: Washington, DC, USA, 2001.

2. Bosch, C.; Hommann, K.; Rubio, G.M.; Sadoff, C.; Travers, L. Water, Sanitation and Poverty Chapter, Poverty Reduction Strategy Papers' Source Book; World Bank: Washington, DC, USA, 2001.

3. Mabogunje, A.L. Poverty and environmental degradation: Challenges within the global economy. Sci. Policy Sustain. Dev. 2002, 44, 8-19. [CrossRef]

4. World Commission for Environment and Development. Our Common Future; Oxford University Press: Oxford, UK, 1987.

5. Moseley, W.G. Environmental degradation and the "poor" smallholders in the West African Sudano-Sahel: Global discourses and local realities. In African Environment and Development: Rhetoric, Programmes, Realities; Moseley, W.G., Logan, B.I., Eds.; Ashgate Publishing: Aldershot, UK, 2004; pp. 41-62.

6. Ravnborg, H.M. Poverty and environmental degradation in the Nicaraguan Hillsides. World Dev. 2003, 31, 1933-1946. [CrossRef]

7. Swinton, S.M.; Quiroz, R. Is poverty to blame for soil, pasture and forest degradation in Peru's Altiplano? World Dev. 2003, 31, 1903-1919. [CrossRef]

8. Gray, C.L.; Moseley, W.G. A geographical perspective on poverty-environmental interactions. Geogr. J. 2005, 171, 9-23. [CrossRef]

9. Duraiappah, A.K. Poverty and environmental degradation: A review and analysis of the nexus. World Dev. 1998, 12, 2169-2179. [CrossRef]

10. Angelsen, A. The poverty of the environment and the environment of poverty. In Poverty and the Environment, Proceedings of the CROP/ADIPA/UNCTAD workshop, Sabah, Malaysia, October 1995; Angelsen, A., Vainio, M., Eds.; Comparative Research Programme on Poverty (CROP) Publications: Bergen, Norway, 1998; pp. 2-18.

11. Boyce, J.K. Inequality as a cause of environmental degradation. Ecol. Econ. 1994, 11, 169-178. [CrossRef]

12. Leach, M.; Mearns, R.; Scoones, I. Environmental Entitlements: Dynamics and Institutions in Community-Based Natural Resource Management. World Dev. 1999, 2, 225-247. [CrossRef]

13. Forest Investment Program. REDD Preparation Plan; Ministry of Environment and Sustainable Development: Ouagadougou, Burkina Faso, 2012.

14. Kambire, H.W.; Djenontin, I.N.S.; Kabore, A.; Djoudi, H.; Balinga, M.P.B.; Zida, M.; Assembe-Mvondo, S. La REDD+ et l'Adaptation aux Changements Climatiques au Burkina Faso: Causes, Agents et Institutions; CIFOR: Bogor, Indonesia, 2015.

15. Kaminski, J.; Headey, D.; Bernard, T. The Burkinabe cotton story 1992-2007: Sustainable success or sub-saharan mirage? World Dev. 2011, 39, 1460-1475. [CrossRef]

16. Ouedraogo, I.; Savadogo, P.; Tigabu, M.; Cole, R.; Odén, P.C.; Ouadba, J.M. Is rural migration a threat to environmental sustainability in Southern Burkina Faso? Land Degrad. Dev. 2009, 20, 217-230. [CrossRef]

17. Johnson, D.L.; Ambrose, S.H.; Bassett, T.T.; Bowen, M.L.; Crummey, D.E.; Isaacson, J.S.; Johnson, D.N.; Lamb, P.; Saul, M.; Winter-Nelson, A.E. Meanings of environmental terms. J. Environ. Qual. 1997, 26, 581-589. [CrossRef]

18. Abu Hammad, A.; Tumeizi, A. Land degradation: Socioeconomic and environmental causes and consequences in the eastern Mediterranean. Land Degrad. Dev. 2012, 23, 216-226. [CrossRef]

19. Mortimore, M. The Future of Family Farms in West Africa: What Can We Learn from Long-Term Data?; Drylands Issue Paper No. 119; IIED: London, UK, 2003.

20. Belem, M.; Bayala, J.; Kalinganire, A. Defining the poor by the rural communities of Burkina Faso: Implications for the development of sustainable parkland management. Agrofor. Syst. 2011, 83, $287-302$. [CrossRef]

21. United Nations Development Programme (UNDP). Human Development Report 2006-Beyond Scarcity: Power, Poverty and the Global Water Crisis; United Nations Development Programme (UNDP): New York, NY, USA, 2006.

22. Chomitz, K. At loggerheads? Agricultural Expansion, Poverty Reduction, and Environment in the Tropical Forests; World Bank Policy Research Report; World Bank: Washington, DC, USA, 2007. 
23. Ouedraogo, I.; Tigabu, M.; Savadogo, P.; Compaoré, H.; Odén, P.C.; Ouadba, J.M. Land cover change and its relation with population dynamics in Burkina Faso, West Africa. Land Degrad. Dev. 2010, 21, 453-462. [CrossRef]

24. Paré, S.; Söderberg, U.; Sandewall, M.; Ouadba, J.M. Land use analysis from spatial and field data capture in Southern Burkina Faso, West Africa. Agric. Ecosyst. Environ. 2008, 127, 277-285. [CrossRef]

25. Ingram, K.T.; Roncoli, M.C.; Kirshen, P.H. Opportunities and constraints for farmers of West Africa to use seasonal precipitation forecasts with Burkina Faso as a case study'. Agric. Syst. 2002, 74, 331-349. [CrossRef]

26. Driessen, P.; Deckers, J.; Spaargaren, O. Lectures Notes on the Major Soils of the World; FAO World Soil Resources, Report-94; Food and Agriculture Organization of the United Nations: Rome, Italy, 2001.

27. Institut National des Statistiques et de la Démographie (INSD). Résultats Préliminaires du Recensement Général de la Population et de l'Habitat de 2006; Institut National des Statistiques et de la Démographie (INSD), Direction de la Démographie: Ouagadougou, Burkina Faso, 2007.

28. Fontes, J.; Guinko, S. Carte de Végétation et de l'Occupation du sol du Burkina Faso; Projet Campus; UPS: Toulouse, France, 1995.

29. Balen, J.; McManus, D.; Yue-Sheng, L.; Zheng-Yuan, Z.; Li-Ping, Y.; Utzinger, J.; Williams, G.M.; Li, Y.; Ren, M.Y.; Liu, Z.C.; et al. Comparison of two approaches for measuring household wealth via an asset-based index in rural and Peri-urban settings of Hunan province, China. Emerg. Themes Epidemiol. 2010, 7, 7. [CrossRef] [PubMed]

30. Laderchi, C.R.; Saith, R.; Stewart, F. Does it matter that we do not agree on the definition of poverty? A comparison of four approaches. Oxf. Dev. Stud. 2003, 31, 243-274. [CrossRef]

31. Weng, X. The Rural Informal Economy: Understanding Drivers and Livelihood Impacts in Agriculture, Timber and Mining; IIED Working Paper; IIED: London, UK, 2015; Available online: http:/ / pubs.iied.org/16590IIED. html?r=p (accessed on 15 March 2016).

32. Booysen, F.; van der Berg, S.; Burger, R.; van Maltitz, M.; de Rand, G. Using an asset index to assess trends in poverty in seven sub-Saharan African countries. World Dev. 2008, 6, 1113-1130. [CrossRef]

33. Narayan, D.; Chambers, R.; Shah, M.K.; Petesch, P. Voices of the Poor: Crying out for Change; Oxford University Press USA for the World Bank: New York, NY, USA, 2000.

34. Ouedraogo, I.; Mbow, C.; Balinga, M.; Neufeldt, H. Transitions in land use architecture under multiple human driving forces in a semi-arid zone. Land 2015, 4, 560-577. [CrossRef]

35. Swinton, S.M.; Escobar, G.; Reardon, T. Poverty and environment in Latin America: Concepts, evidence and policy implications. World Dev. 2003, 31, 1865-1872. [CrossRef]

36. Teshome, A.; de Graaff, J.; Ritsema, C.; Kassie, M. Farmers' perceptions about the influence of land quality, land fragmentation and tenure systems on sustainable land management in the north western Ethiopian Highlands. Land Degrad. Dev. 2014. [CrossRef]

37. Ravnborg, H.M.; Escolán, R.M.; Guerrero, M.P.; Méndez, M.A.; Méndoza, F.; de Páez, E.M.; Motta, F. Developing Regional Poverty Profiles Based on Local Perceptions; CIAT Publication No. 291; Centro Internacional de Agricultura Tropical (CIAT): Cali, Colombia, 1999.

38. Etongo, D.; Djenontin, I.N.S.; Kanninen, M.; Fobissie, K.; Korhonen-Kurki, K.; Djoudi, H. Land tenure, asset heterogeneity and deforestation in Southern Burkina Faso. For. Policy Econ. 2015, 61, 51-58. [CrossRef]

39. Gray, L.C. What kind of intensification? Agricultural practices, soil fertility and socioeconomic differentiation in rural Burkina Faso. Geogr. J. 2005, 171, 70-82. [CrossRef]

40. Reenberg, A.; Oksen, P.; Svendsen, J. Land use Changes vis-à-vis agricultural development in Southeastern Burkina Faso: The field expansion dilemma. Geogr. Tidsskr. Dan. J. Geogr. 2003, 103, 57-69. [CrossRef]

41. Jones, D.W.; Dale, V.H.; Beauchamp, J.J.; Pedlowski, M.A.; O’Neill, R.V. Farming in Rondomia. Resour. Energy Econ. 1995, 17, 155-188. [CrossRef]

42. Ouédraogo, M.; Tankoano, A.; Ouédraogo, Z.T.; Guissou, I.P. Etude des facteurs des risques d'intoxications chez les utilisateurs de pesticides dans la region cotonnière de Fada N'Gourma au Burkina Faso. Environ Risque Santé 2009, 8, 343-347.

43. Toe, A.M.; Kinane, M.L. Les pesticides au Burkina Faso/ Pesticide in Burkina Faso, Dakar-Fann. Available online: https://searchworks.stanford.edu/view/9154884 (accessed on 26 July 2015).

44. Toe, A.M.; Ouedraogo, M.; Ouedraogo, R.; Ilboudo, S.; Guissou, P.I. Pilot study on agricultural pesticides poisoning in Burkina Faso. Interdiscip Toxicol 2013, 6, 185-191. [CrossRef] [PubMed] 
45. Brocard, D.; Lacaux, J.P.; Eva, H. Domestic biomass combustion and associated atmospheric emissions in West Africa. Glob. Biogeochem. Cycle 1998, 12, 127-139. [CrossRef]

46. Kituyi, E.; Marufu, L.; Huber, B.; Wandiga, S.O.; Jumba, I.O.; Andreae, M.O.; Helas, G. Biofuel consumption rates and patterns in Kenya. Biomass Bioenergy 2001, 20, 83-99. [CrossRef]

47. Niemeijer, D.; Mazzucato, V. Soil degradation in the West African Sahel: How serious is it? Environ. Sci. Policy Sustain. Dev. 2002, 44, 20-31. [CrossRef]

48. Larwanou, M.; Saadou, M. The role of human interventions in tree dynamics and environmental rehabilitation in the Sahel zone of Niger. J. Arid Environ. 2011, 75, 194-200. [CrossRef]

49. Place, F.; Binam, J.N. Economic Impacts of Farmer Managed Natural Regeneration in the Sahel: End of Project Technical Report; Free University, International Fund for Agricultural Development (IFAD): Amsterdam, NY, USA, 2013.

50. Weston, P.; Hong, R.; Kaboré, C.; Kull, C.A. Farmer-managed natural regeneration enhances rural livelihoods in dryland West Africa. Environ. Manag. 2015, 55, 1402-1417. [CrossRef] [PubMed]

51. Nabahungu, N.L.; Visser, S.M. Farmers' knowledge and perception of agricultural wetland management in Rwanda. Land Degrad. Dev. 2013, 24, 363-374. [CrossRef]

52. Karltun, E.; Lemenih, M.; Tolera, M. Comparing farmers' perception of soil fertility change with soil properties and crop performance in Beseku, Ethiopia. Land Degrad. Dev. 2013, 24, 228-235. [CrossRef]

53. Morgan, G.A.; Leech, N.L.; Gloeckner, G.W.; Barrett, K.C. SPSS for Introductory Statistics: Use and Interpretation, 2nd ed.; Lawrence Erlbaum Associates: Mahwah, NJ, USA, 2004.

54. Hilton, A.; Armstrong, R.A. Is one set of data more variable than another? Microbiologist 2006, 7, 34-36.

55. Field, A.P. Discovering Statistics Using IBM SPSS Statistics: And Sex and Drugs and Rock'n'roll, 4th ed.; Sage: London, UK, 2013.

56. Ton, P. Cotton Production and Rural Livelihoods in West Africa; Oxfam: Oxford, UK, 2001.

57. Bonnassieux, A. Filière coton, émergence des organisations de producteurs et transformations territoriales au Mali et au Burkina Faso. Les Cahiers d'Outre-Mer 2002, 220, 421-434. [CrossRef]

58. Sawadogo, L. Adapter les Approches de l'Aménagement Durable Des Forêts Sèches Aux Aptitudes Sociales, Economiques et Technologiques en Afrique; Center for International Forestry Research (CIFOR): Bogor, Indonesia, 2006.

59. Ndiaye, O.; Zoungrana, P. Techniques de maintien de la fertilité des sols: Une Revolution Silencieuse de l'Agriculture. Available online: http://www.inter-reseaux.org/auteur/philippe-zoungrana (accessed on 30 December 2014).

60. Ouédraogo, E.; Mando, A.; Zombré, N.P. Use of compost to improve soil properties and crop productivity under low input agricultural system in West Africa. Agric. Ecosyst. Environ. 2001, 84, 259-266. [CrossRef]

61. Reij, C.; Tappan, G.; Belemvire, A. Changing land management practices and vegetation on the Central Plateau of Burkina Faso (1968-2002). J. Arid Environ. 2005, 63, 642-659. [CrossRef]

62. McClintock, N.C.; Diop, A.M. Soil fertility management and compost use in Senegal's Peanut Basin. Int. J. Agric. Sustain. 2005, 3, 1473-5903. [CrossRef]

63. Ouédraogo, M. Land Tenure and Rural Development in Burkina Faso: Issues and Strategies; Issue Paper No. E112; International Institute for Environment and Development (IIED): London, UK, 2002; Available online: http:/ / www.iied.org/ (accessed on 4 June 2014).

64. Bai, Z.G.; Dent, D.L.; Olsson, L.; Schaepman, M.E. Proxy global assessment of land degradation. Soil Use Manag. 2008, 24, 223-234. [CrossRef]

65. Lenhardt, A.; Glennie, J.; Intscher, N.; Ali, A.; Morin, G. A Greener Burkina: Sustainable Farming Techniques, Land Reclamation and Improved Livelihoods; Development Progress Case Study Report; Overseas Development Institute: London, UK, 2014; Available online: http://www.odi.org/sites/odi.org.uk/files/odi-assets/ publications-opinion-files/9153.pdf (accessed on 5 January 2015).

66. Robinson, B.E.; Holland, M.B.; Naughton-Treves, L. Does secure land tenure save forest? A meta-analysis of the relationship between land tenure and tropical deforestation. Glob. Environ. Chang. 2013, 29, $281-293$. [CrossRef]

67. Ajayi, O.C.; Franzel, S.; Kuntashala, E.; Kwesiga, F. Adoption of improved fallow technology for soil fertility management in Zambia: Empirical studies and emerging issues. Agrofor. Syst. 2003, 59, 317-326. [CrossRef] 
68. Kenta, I.; Shinjo, H.; Tanaka, U.; Tobita, S.; Funakawa, S.; Kosaki, T. Fallow Band System, a land management practices for controlling desertification and improving crop production in the Sahel, West Africa, Effectiveness in desertification control and soil fertility improvement. Soil Sci. Plant Nutr. 2011, 57, 573-586.

69. Somda, J.; Nianogo, A.J.; Nassa, S.; Sanou, S. Soil fertility management and socio-economic factors in crop-livestock systems in Burkina Faso: A case study of composting technology. Ecol. Econ. 2002, 43, 175-183. [CrossRef]

70. Zougmore, R.; Gnankambary, Z.; Guillobez, S.; Stroosnijder, L. Effects of stone lines on soil chemical characteristics under continuous sorghum cropping in semiarid Burkina Faso. Soil Tillage Res. 2002, 66, 47-53. [CrossRef]

71. Kaboré, D.; Reij, C. The Emergence and Spreading of an Improved Traditional Soil and Water Conservation Practice in Burkina Faso; EPTD Discussion Paper No. 114; International Food Policy Research Institute: Washington, DC, USA, 2004; Available online: http://www.ifpri.org/publication/emergence-and-spreading-improvedtraditional-soil-and-water-conservation-practice-burkin (accessed on 31 December 2014).

72. Leenders, J.K.; Sterk, G.; van Boxel, J.H. Wind erosion reduction by scattered woody vegetation in farmers' fields in northern Burkina Faso. Land Degrad. Dev. 2014. [CrossRef]

73. Grimaldi, S.; Angeluccetti, I.; Coviello, V.; Vezza, P. Cost-effectiveness of soil and water conservation measures on the catchment sediment budget-The Laaba watershed case study, Burkina Faso. Land Degrad. Dev. 2013. [CrossRef]

(C) 2016 by the authors; licensee MDPI, Basel, Switzerland. This article is an open access article distributed under the terms and conditions of the Creative Commons Attribution (CC-BY) license (http://creativecommons.org/licenses/by/4.0/). 